\title{
THE ROLE OF MANAGEMENT OF THE FIELD-FOREST BOUNDARY IN POLAND'S PROCESS OF AGRICULTURAL RESTRUCTURING
}

\author{
FRANCISZEK WOCH, ROBERT BOREK \\ Institute of Soil Science and Plant Cultivation - State Research Institute \\ 24-100 Puławy, Czartoryskich 8, Poland \\ e-mail: rborek@iung.pulawy.pl
}

\begin{abstract}
The aim of the work described here has been to point to the relationships between the field-forest boundary and crop productivity as regards the present agrarian land-use structure in Poland, and to provide new opportunities for arranging the agrarian process and the spatial planning of the rural landscape in the context of the sustainable shaping of the field-forest boundary. Impacts of forests and woodlands on crop productivity have been assessed using available data from relevant Polish literature. An assessment of the plot-distribution pattern characterising farms in Poland was made on the basis of reference data from the Agency for the Restructuring and Modernisation of Agriculture. Finally, the possibility of afforestation of agricultural land has been evaluated within the existing legal framework, and on the basis of available data, with attention paid to the need to include organization of the field-forest boundary within the comprehensive management and planning of rural areas, and to preserve woody elements in patchy landscapes. This all creates an opportunity to test innovative approaches to integrated land use which combines the creation of public goods and local products based on participatory learning processes that bring in local stakeholders and decision-makers.
\end{abstract}

KEY WORDS: afforestation, field-forest boundary, agrarian structure, arranging the agrarian process, integrated land use, agroforestry. 


\section{INTRODUCTION}

The challenge facing agricultural land use is to increase crop production per unit area, in order to feed a growing population, while reducing both the negative impacts on the environment, including biodiversity loss and climate change impacts. Landscape structure is one of the main determinants of agricultural productivity, and large parts of Poland's rural areas are characterised by a fragmented structure of agrarian land. The south and east, in particular, have many small farms characterised by plot fragmentation and low-intensity management. This is in marked contrast to the intensive farming systems of northern and western Poland, and it reflects the affiliation of the latter regions with Prussian in the years 1793 to 1918, following the partitioning of Poland. A feature in the formerly-Prussian areas is the presence of large-scale landed properties which were transformed post-1945, into large State Farms and agricultural cooperatives. When the communist system collapsed, the farmland in question was purchased by many different private owners, or else tenanted or sold from/by the Treasury Agricultural Property Agency, which nevertheless retains a considerable acreage (Markuszewska 2013). However, the ownership situation in these areas has been very dynamic in recent years, and further changes in land-use structure are to be expected due to growing interest in land purchases.

In contrast, it is in south-eastern Poland that the most fragmented agrarian structure occurs, this mainly reflecting historical and natural conditioning, including as regards soil diversity, the inheritance-related division of land and presence of a high-density population in rural areas. Land fragmentation, reflected in the so-called field patchwork or "chessboard" is believed to generate transport, labour and production costs. As such, this structure might be an important factor limiting the local development of rural areas, and capable of hampering improved food production efficiency, as well as reducing the potential for innovation.

In the light of the above, a solution suggested for rural areas is a transformation of their spatial structure, mostly through land consolidation. From 1982 onwards, Poland applied the Act on Land Consolidation and Exchange (as amended in 2011) as an instrument by which to address these problems (Ustawa o scalaniu $i$ wymianie gruntów... 2011). Since Poland's EU accession of 2004, land consolidation has been funded under the Rural Development Programme (RDP). Nevertheless, the positive effects of land consolidation in Poland remain negligible. Moreover, the process can affect the rural environment adversely due to simplification of rural landscape structure, and agricultural intensification. To increase resilience to climate change and reduce greenhouse gas emissions, more diversified land use is needed. In this context, particular attention is paid to trees, these being a source of biomass and timber on the one hand, while forming the basis for the provision of ecosystem services in the agricultural landscape on the other. Also stressed often are the roles of woody strips (shelterbelts, hedgerows) and woodlands in: enhancing the local water balance (Ryszkowski and Kędziora 1987), preventing water and wind erosion (Węgorek 1997) and protecting 
water quality (Ryszkowski and Kędziora 2007), as well as biodiversity conservation and enhancement (Ryszkowski 2002). Today, introduction of landscape features as Ecological Focus Areas (EFA) (based on Common Agricultural Policy (CAP) greening criteria) and eco-corridors (within ecological policies) is required. Hence, new alternative approaches to land grouping and parcel allocation, connected with the multifunctional development of rural areas are proposed. Among other things, the suggestions include afforestation of non-fertile soil, the establishment of mid-field scrub to prevent soil erosion, the introduction of mid-field balks, lines of shrubs and other linear landscape elements purifying ground water, and delineation of non-cultivated refuges to increase biodiversity - including field-forest boundary (Markuszewska 2013, Kupidura 2010).

The rural-forest boundary (hereafter referred to as "field-forest boundary") is a boundary designed with account taken of soil and ecological-landscape criteria and set as the legal boundary for land-use shaping structure. The borderline allows for the management of afforestation processes in communities (Wytyczne... 2003, Woch 1996). At present, strips along the forest border are also included on the list of EFAs among the measures for the greening of the CAP 2014-2020, thus making the subject of the field-forest boundary an important one. The topic of the field-forest boundary is developed to only a limited extent in Poland (Woch 2001, Woch and Tałałaj 2007). The beneficial impact of natural forest/woodland vegetation on adjacent field crops is not well understood, though is known to depend mainly on tree species present, their height, roots competition, the exposure of the forest edge, soil quality and slope inclination. Some researchers have developed optimisation rules for patterns of plot distribution in a fragmented agricultural landscape, taking account of environmental factors, including the benefits accruing from the introduction of trees and shrubs (Woch and Tałałaj 2007, Woch 2006). Others have proposed farmland afforestation (understood as a mosaic pattern of shelterbelts and woodlots) as an urgent need for the regions of Poland (Zajączkowski 2005, Zajączkowski and Zajączkowski 2009, Ryszkowski et al. 2000) Still others have focused on the influence of soil conditions on shaping the structure of the rural landscape, where afforestation should be carried out on low-quality soils, soils susceptible to erosion and those along streams, where the aim is to prevent the eutrophication of waters (Bielska and Kupidura 2009).

This paper focuses on key aspects of the shaping of the field-forest boundary in the context of Poland's agricultural restructuring process, and in terms of the present agrarian land structure. The aim is to point to relationships between the boundary and crop productivity, on the basis of studies conducted thus far; as well as to suggest new opportunities for the sustainable and multifunctional spatial planning of a "landsharing" rural landscape in the context of agroecological shaping of the field-forest boundary. 


\section{DATA AND METHODS}

The focus of this study has entailed assessments of: (1) the impact of afforested land on crop productivity on farms, (2) plot distribution patterns on Polish farms, (3) the possibilities for agricultural land to be afforested or made subject to tree-planting, including through the establishment of woodlands, hedges or tree lines.

The impacts of forests and woodlands on crop productivity were assessed using data available from the relevant Polish literature.

Assessment of the plot distribution pattern in Poland was in turn performed using 2013 reference data for the Agency for the Restructuring and Modernisation of Agriculture (ARMA). ARMA has the role of implementing institution and paying agency within the framework of the CAP in Poland.

Finally, the possibilities as regards afforestation or tree planting on agricultural land were evaluated within the legal framework, on the basis of available data.

\section{RESULTS OF INVESTIGATION}

\section{THE ASSESSED IMPACT OF AFFORESTED LAND ON THE PRODUCTIVITY OF FARM CROPS}

Due to difficult conditions characterising agrarian structure and specific historical determinants of the rural landscape in Poland, studies on the impact of trees on crops have been an important element of agricultural studies. The issue is particularly crucial for farmers, given that abandonment of agricultural land in recent decades has mainly reflected the limited capacity of soil to sustain agriculture and the impact of afforested land in the vicinity.

Figure 1 depicts a generalised model for the impact of a shelterbelt on cereal grain productivity, as developed under Polish conditions by Tałałaj (1997). Although crop

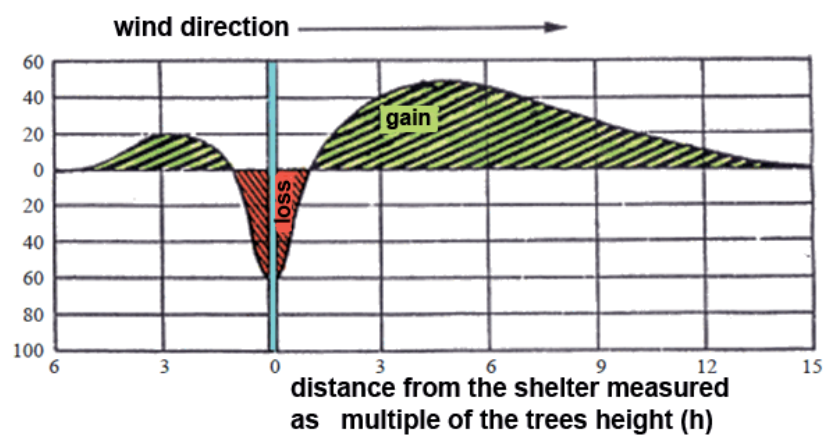

Figure 1. Graph, presenting the generalised impact of distance from shelterbelt (horizontal axis) on relative crop productivity (vertical axis) - after Tałałaj 1997, modified 
yields are affected negatively by trees in the immediate vicinity, a rapid logarithmic increase in yield is to be observed at greater distances from the shelter. Where the profitability of grain yields to the farmer is concerned, the increase may be even of $20 \%$ at a distance equal to 3 times the height of trees, and of $50 \%$ at a distance 5 times the height of trees on the lee side and on the leeward side of the shelter, respectively, followed by a slow decrease in yields at still-greater distances.

Studies carried out in western Poland over the past 50 years have shown that the network of shelterbelts plays a multifunctional role in controlling the processes of energy flow and matter cycling in the agricultural landscape. It increases the efficiency of use of nutrients by providing a "safety-net" to filter those which are leached below crop-roots, as well as allowing for improved micrometeorological conditions of crop fields, contributing to the enrichment of biological diversity and the improvement of the water-balance structure of agricultural fields located between shelterbelts. An assessment of the benefits to local water balance is presented in Figure 2. The positive effect of trees on crop productivity might be also be explained by resistance to erosion and the storage of organic matter.

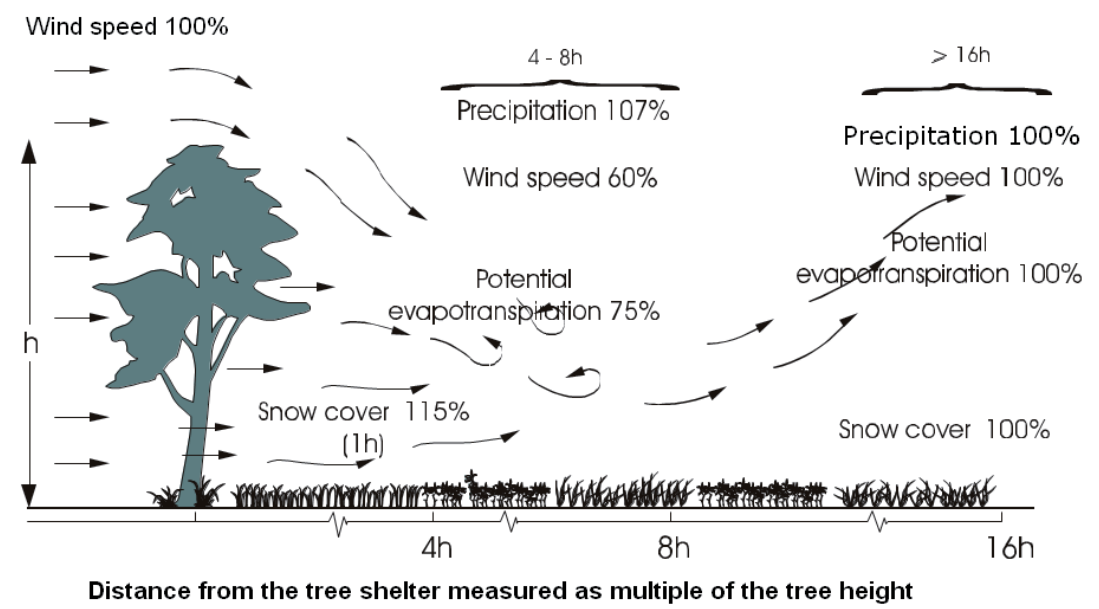

Figure 2. Impact of a shelterbelt on the microclimate of adjacent fields (after Molga 1983)

The vertical axis shows height of the shelterbelt.

Results of studies by Woch $(1993,1996,2001)$ reveal an important relationship between the distance from the forest/woodland edge and crop yield. To estimate this, analysis was performed on almost 1000 grain yield samples (averaged over the species: rye, winter and spring wheat, winter triticale, barley and oats - details not shown). The samples were collected during the harvest period of the 1993 season from plots near the forest or woodland boundaries. The selected plots (covering $0.15 \mathrm{~m}^{2}$ each) were located at distances ranging from $1 \mathrm{~m}$ from the forest edge to a distance equal to 
double or triple the heights of trees. The samples were thrashed and weighted (Woch et al. 1993). Cereal yields in the immediate vicinity of trees are at only $8-15 \%$ of the average yield for the area excluding the edge zone (Fig. 3). However, at successively greater distances from the edge up to 1.5 times the equivalent of tree height crop yields were found to increase, only increasing slightly or not changing thereafter. Moreover, the adverse effect of forest was shown to relate to soil quality, cereal species, tree height and slope exposure. The most adverse effect was to be observed on poor-quality soils (arable land of Classes IV-VI), within distances equivalent to between 0 and 2.0 (on average 1.3) times the heights of trees, depending on crop and tree species. The least-negative impact of trees was observed on good-quality soils (of Class I-III arable land), within distances of $0.5-1.0$ tree heights ( 0.8 tree heights on average). A morenegative effect was to be found at edge zones oriented to the north as opposed to the south (within a distance of 1.3 times the tree height vs. 0.8 times the tree height, respectively). This probably reflected exposure to the sun and soil-nutrient availability. A northern slope inclination was found to increase the edge effect, while a southern slope inclination reduced it (Podolski and Woch 1999). Information needs to be verified by way of further studies taking new plant varieties and modern agricultural technology into account.

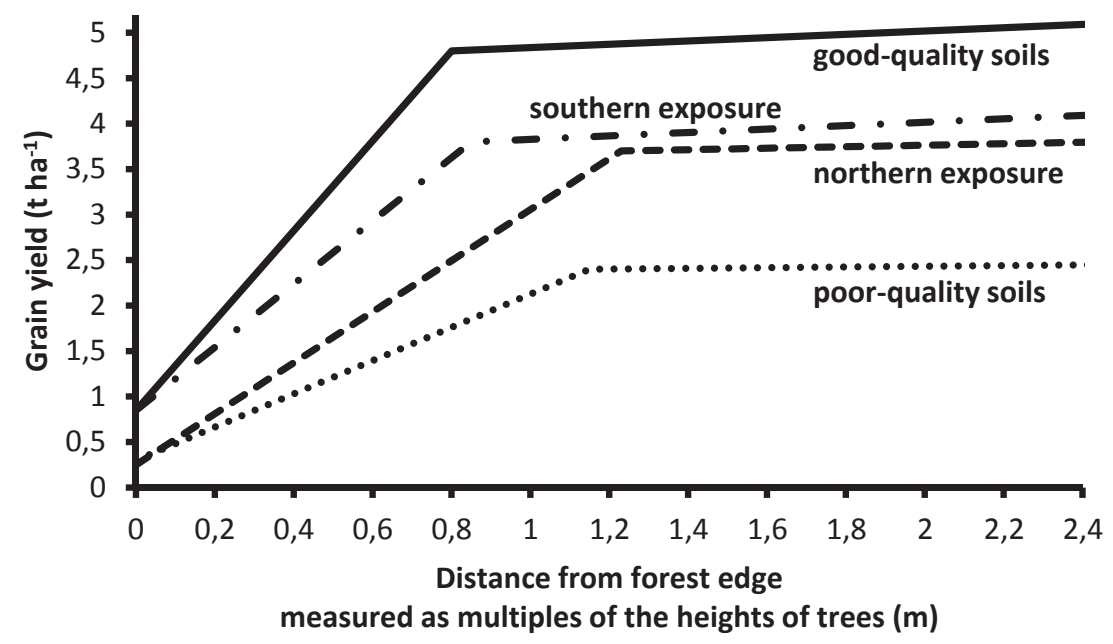

Figure 3. Grain yield affected by distance from the forest edge in relation to soil quality and orientation to the south/north (acc. Woch et al. 1993)

Furthermore, it is important to note that while height and species of tree are essential features of the interaction between crops and trees, these factors were not taken account of in the abovementioned studies. However, the issue has been documented by Polish researchers (Kulig 1959, Jakubczak and Wołk 1977, Lekan et al. 1993, Podolski and Woch 1999). 
ASSESSMENT OF THE PLOT DISTRIBUTION PATTERNS CHARACTERISING POLISH FARMS

Spatial analysis performed for farms in Poland included data from 750000 farming households on farm size and the number and area of farm plots, for all surveying districts, averaged for local-authority areas and voivodships (provinces) - Jędrejek et al. 2014. We confined ourselves to farms that were: subject to the provisions of the Act on Shaping of the Agrarian System (Ustawa o ksztattowaniu ustroju rolnego... 2003) of farm area ranging from 1-300 ha; with farmers declaring personal farming activity and the owners living and farming in the same district. These restrictive criteria ensure that the presented data differ considerably from the original reference data of the Agency for the Restructuring and Modernisation of Agriculture, and the census data from the Central Statistical Office.

The analysis indicates major variation in respect of farm area, as well as land from one region or local-authority area to another. Average size of a farm in Poland has been estimated at circa 16 ha, but ranges between 20 ha in the north and 5 ha in the south (data not shown). The average areas of plots in local-authority areas differs from province to province (Fig. 4). In northern and north-western Poland, average plot sizes

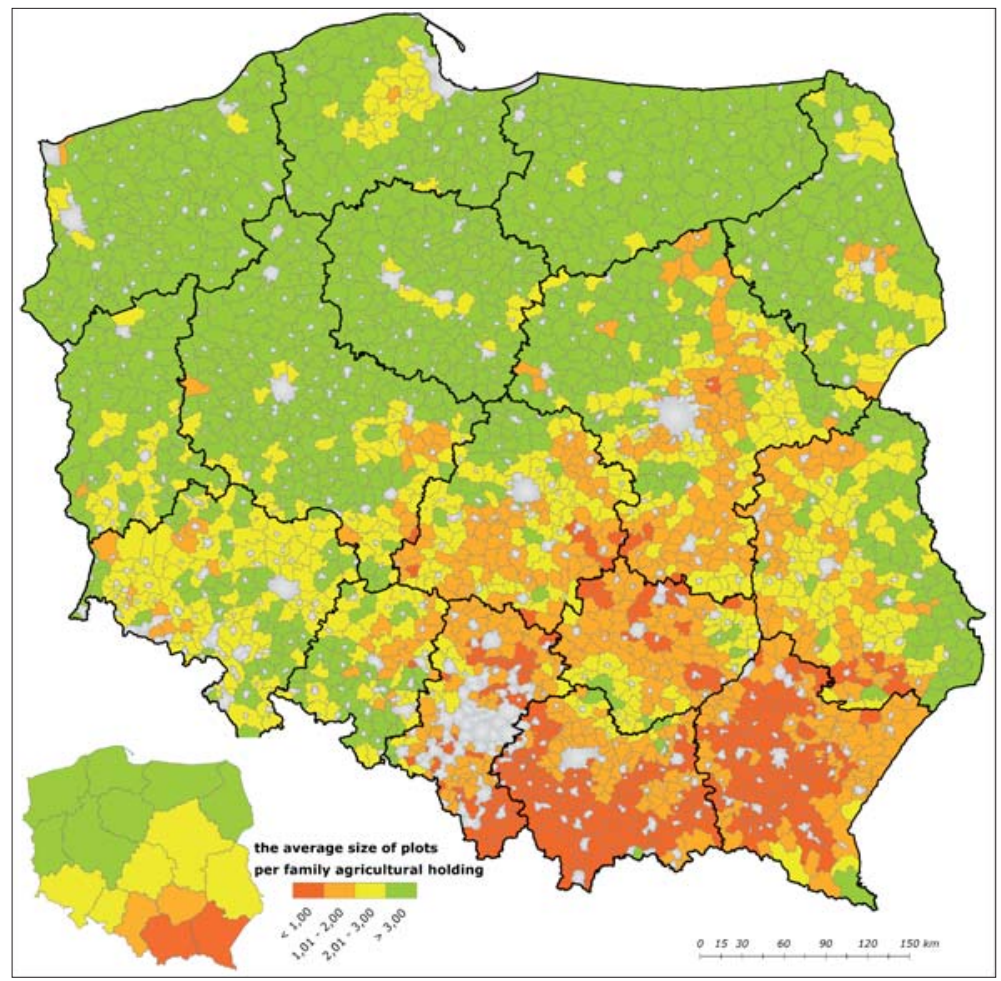

Figure 4. Average sizes of plots (ha) per family agricultural holding in Poland, as ranked by local authority areas (after Jędrejek et al. 2014) 
exceed 3 ha (in Zachodniopomorskie, Warmińsko-Mazurskie, Pomorskie, KujawskoPomorskie, Wielkopolskie, Podlaskie and Lubuskie). In the south-eastern and central regions the range is 1-2 ha (in Śląskie, Świętokrzyskie, Łódzkie, Lubelskie, Mazowieckie, Dolnośląskie and Opolskie voivodships). The smallest plots (of less than 1 ha) are in turn found in southern Poland (in Małopolskie and Podkarpackie voivodships) - Jędrejek et al. 2014.

Similar diversity was observed as regards the numbers of plots per farm (Fig. 5). In north-central and western provinces the typical number of plots was around 5 and in the range 4-7, while in the southern and eastern voivodships, the average number was in the range 6-8. An extremely unfavourable distribution of land characterises southern provinces (of Małopolskie and Podkarpackie), where the average number of parcels per farm is in the range 7-8 (Jędrejek et al. 2014). In addition, the distances between a farm and cultivated plots can be considerable, at up to $3-4 \mathrm{~km}$ (Woch 2006).

It should be noted that a large number of farms in Poland have not been included within the system of EU direct support schemes, due to small farm size. Adverse plot structure further exacerbates the dire financial situation of households.

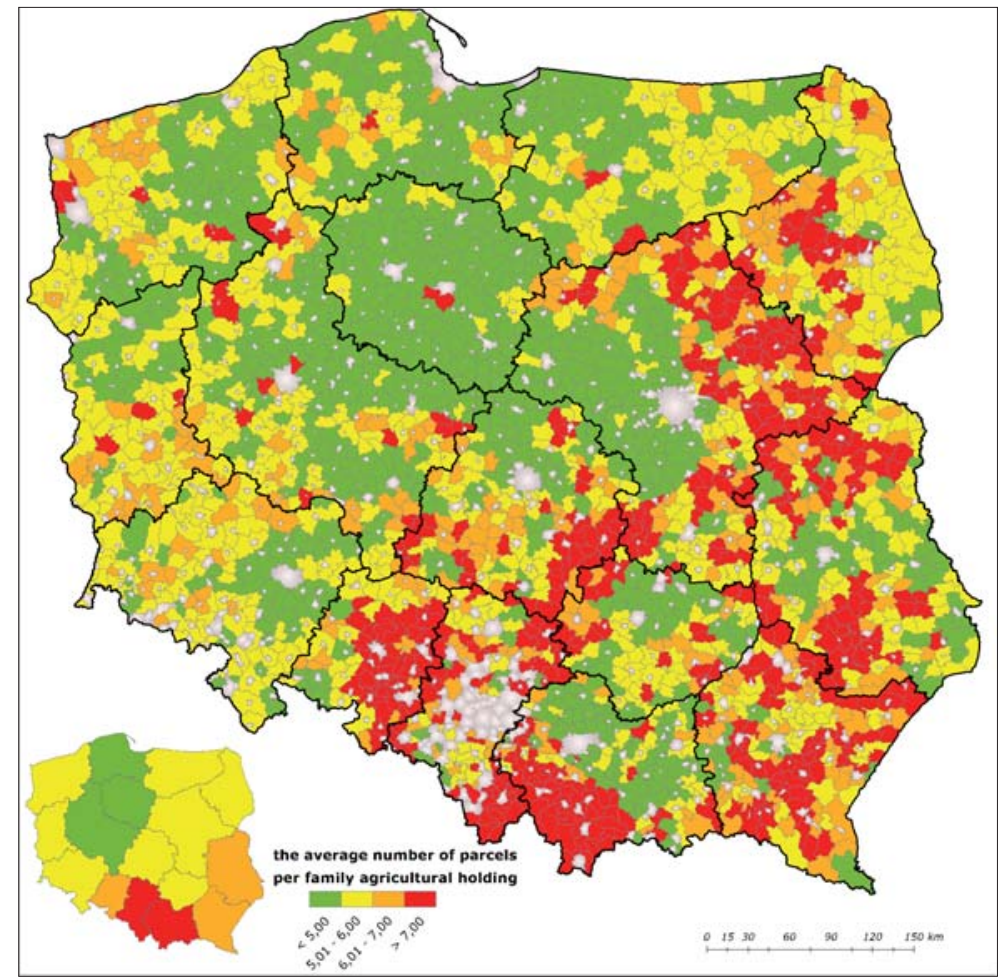

Figure 5. The average number of farm plots in Poland, ranked by local authority areas (after Jędrejek et al. 2014) 
ASSESSMENT OF THE POSSIBILITIES FOR AFFORESTING AGRICULTURAL LAND

The main instrument governing afforestation activity in Poland is the National Programme for the Augmentation of Forest Cover (1995), which assumes an increase in the forested area in Poland as a whole to 33\% by 2050 (Krajowy ... 1995). One of the main factors taken into account in afforestation plans is the natural quality of agricultural space, including as regards the presence of poor-quality soil. Additionally, there is a continuing risk of the abandonment of marginal areas to tree cover. Most Polish soils are of inherently low fertility, given the nutrient-pool parent materials. A major limiting factor where soil quality is concerned is the high level of acidity, mostly due to natural causes, but also intensified significantly by anthropogenic factors, through fertilizer application and deposition from the atmosphere. $26 \%$ and $30 \%$ of arable soils are reported to be very acid or acidic, respectively (Stuczyński et al. 2007). Due to the low-quality soils and fragmented agrarian structure and the fact that forest cover is subject to lower tax than agricultural land, some of the latter is allowed to regenerate naturally into forest, through natural succession (Photos $1 \mathrm{a}, \mathrm{b}$ ).

The above considerations, some authors point out that, at the current rate of afforestation, the target set in the afforestation programme will prove hard to reach (Kaliszewski 2012). Post-2003 (when 26500 ha were afforested), the annual rate of afforestation decreased rapidly, to $c a 5000$ hectares in 2013 (Fig. 6).

The reasons for that breakdown are considered to be the competitiveness of direct payments for agricultural production compared with the afforestation premium, the complicated procedures on which grants of financial support depend, the enlargement of minimal plot areas supported by the afforestation premium from 0.1 ha to 0.3 ha in 2004, and up to 0.5 ha in 2007, the exclusion of permanent grasslands from afforestation,

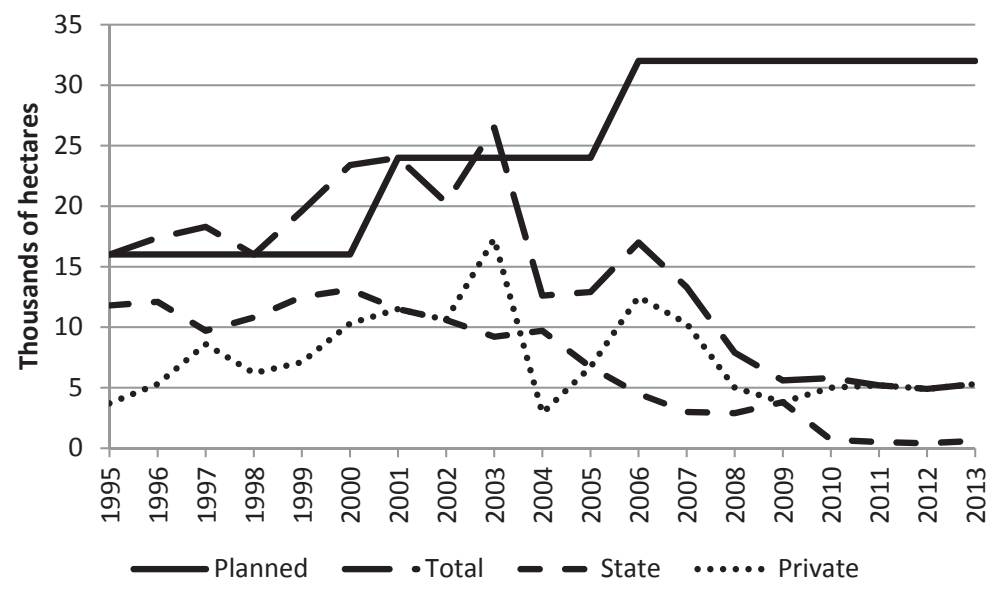

Figure 6. Afforestation activity in Poland in the period 1995-2013

(source of data: www.lasy.gov.pl) 


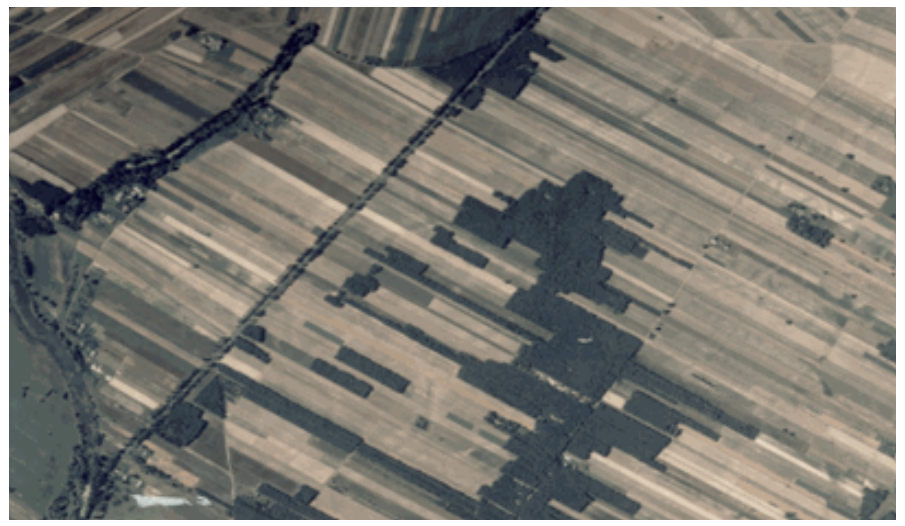

Photo 1 a

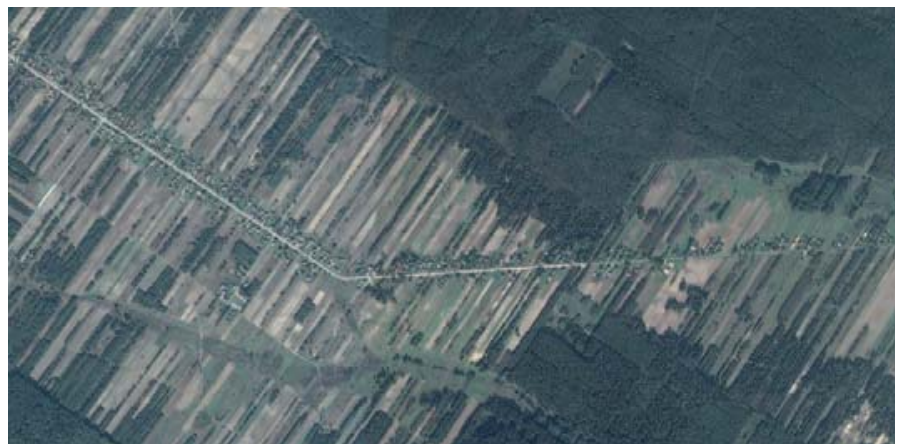

Photo $1 \mathrm{~b}$

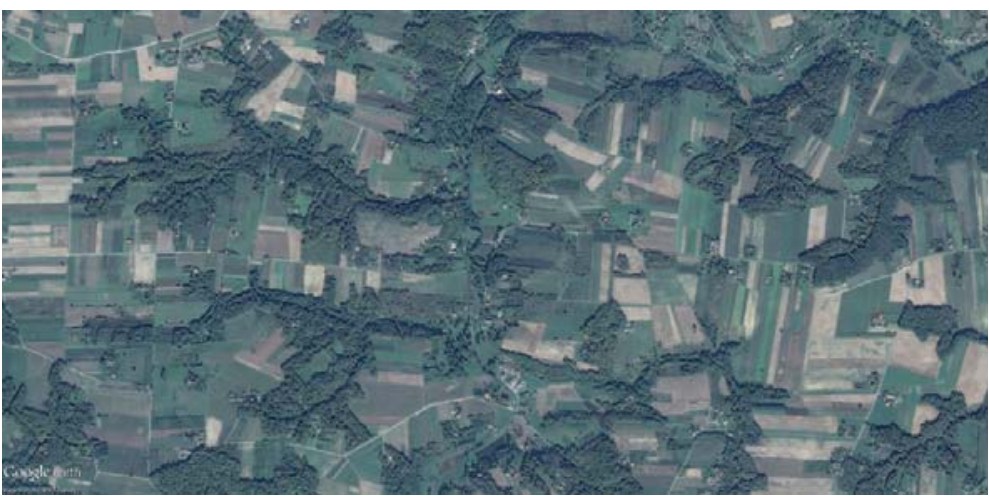

Photo $1 \mathrm{c}$

Photo 1. An example of the plot distribution pattern in a fragmented agricultural landscape at Jabłonów, near Zwoleń, Mazovian Lowland (a), progressive forest succession on abandoned narrow plots at Kierz Niedźwiedzi, near Skarżysko-Kamienna, Małopolska/Lesser Poland Upland (b) and extremely fragmented agrarian structure with gullies at Rzeczyca, Western Lublin Upland (c) - source: http://mapy.geoportal.gov.pl/imap/?gpmap=gp0 
a lack of financial support for afforestation of land within Natura 2000 areas not yet covered by protection plans, a lack of promotion of financial support for afforestation among farmers and a lack of training as regards implementation and up-to-date local spatial management plans (Kaliszewski 2012). Since the long and narrow parcels that are the legacy of inheritance divisions and the splitting-up of land are major features of the land structure in south-eastern Poland, the planned afforestation of agricultural land is hampered. In turn, such parcels on poor-quality soils are often abandoned by farmers, with the result that these areas become overgrown with shrubs and trees (Photo $1 \mathrm{~b}$ ), and may be capable of exerting a tangible impact where an overall increase in forest cover is concerned. However, new afforestation rules under the RDP for 2014-2020 might facilitate the establishment of forest on agricultural land since such afforestation is supported where areas involved on a farm exceed 0.1 ha in area. This contrasts with the approach under the former RD Programmes, wherein the minimum area of this kind was increased deliberately, and the limit as now defined is consistent with the current definition of forest in Poland. The Act on Forests (1991) states that forest means "the land covered with forest vegetation, of area above 0.1 ha; it includes forest grounds temporarily deprived of forest vegetation" (Ustawa o lasach... 1991).

To summarize, the level of afforestation of agricultural lands is found to be determined to a marked degree by a combination of local economic, structural, social, institutional, and even weather-related factors. From 2004 to 2012, the forest area in Poland was increased by $3.63 \%$, with only on average a $20 \%$ contribution made by afforestation of agricultural land supported by the RDP (Leśnictwo... 2014). Taking into account the 12-year payment period for premiums to compensate for loss of income, we might expect an annual afforestation rate at the level of ca. 4500 ha. Hence, in line with the present trend, an assumed increase in forest cover from the current level (i.e. $31 \%$, according to Leśnictwo... 2014) to $33 \%$ by 2050 is very probable.

However, regional policies need to consider the trade-off between the production of food, feed, fuel and fibre crops and ecosystem services. In order to achieve appropriate spatial planning of rural areas in the direction of multifunctional development, management of the landscape should include the organisation of the rural field-forest boundary within the framework of local spatial development plans. In some cases, co-ownership, unknown or unclear ownership of land parcels might be a problem, but it is out of the scope of the paper.

As regards the delineation of rural field-forest boundaries, the guidelines from Poland's Ministry of Agriculture (2003) define areas designated for afforestation in Poland as arable land of Soil Class VI, classified as Land Capability Class 7; arable lands of Soil Class V which are not able to sustain effective crop production, classified as Land Capability Class 6; and pastures of Soil Class VI, located where the water table is low and adjacent to forest complexes. In justified cases, lands to be afforested is wasteland suitable for afforestation; agricultural enclaves $<2$ ha; steep slopes; seepage spring areas; land along the banks or shores of rivers, lakes and ponds, if they are not protected; and degraded land. Forest area should be increased close to 
forest core areas, forest eco-corridors, lakes and rivers (here as patches on 50-60\% of banks or shores), in order to create ecotonal zones that are as wide as possible (Wytyczne... 2003).

The course of a boundary should reflect natural, physiographic and soil conditions and the present use made of arable land (Photo 2). As the field-forest boundary is an ecotone zone, it is recommended that forest vegetation structure and composition be diversified with a view to crop productivity and the functionality of forest both being enhanced (Photo 3). Brzeziecki (2001) recommends the introduction of three sub-zones: a tree zone (growing large), a tree-shrub zone (with smaller trees) and a shrub zone. The zone should consist mainly of deciduous species, adapted to local conditions. Modern agroforestry systems could play an important part as regards the transition zone between the field-forest boundary and agricultural land, in accordance with local spatial development plans and in line with ecological infrastructure.

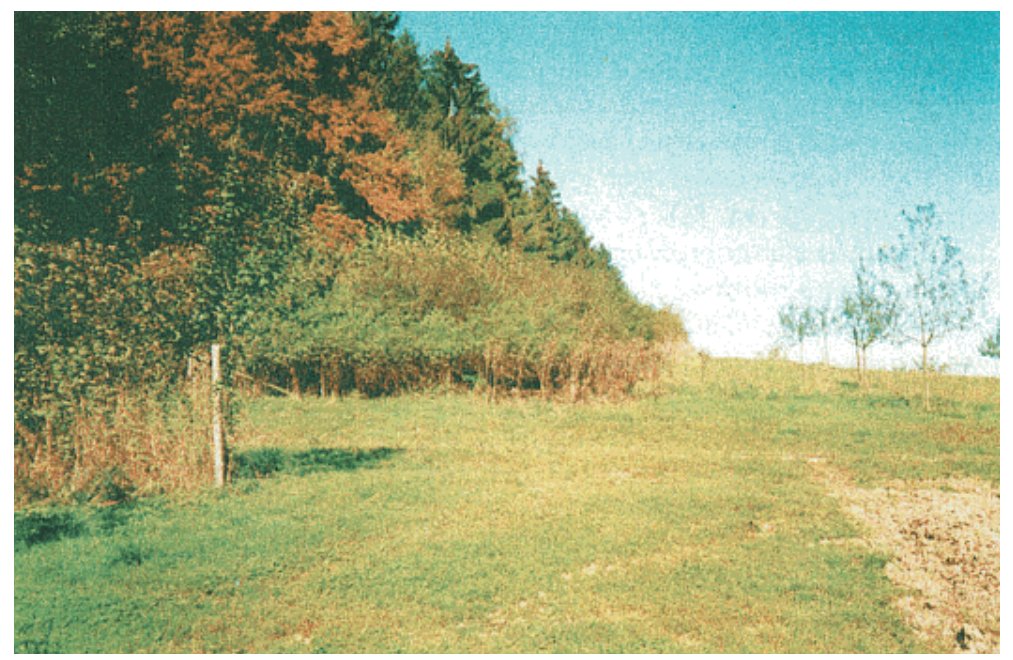

Photo 2. En example of the boundary between field and forest in the landscape (photo: F. Woch)

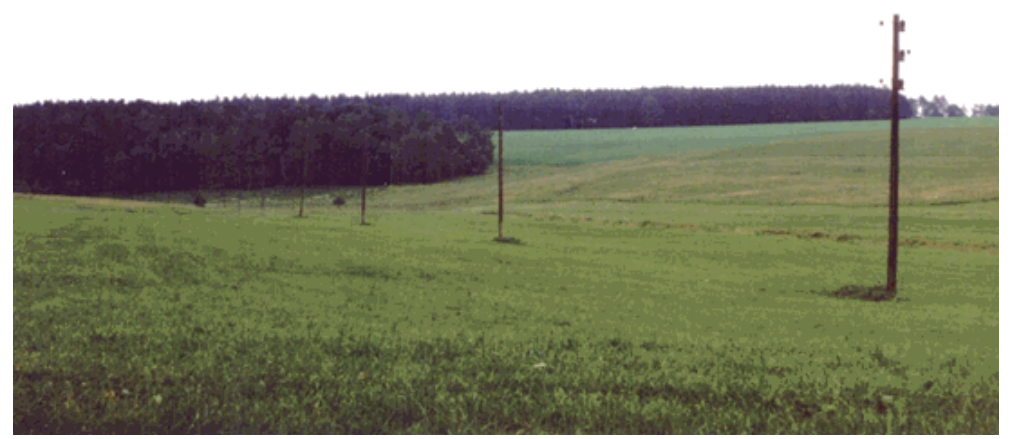

Photo 3. A well-shaped field-forest boundary (photo: F. Woch) 
Supplementary afforestation (including the introduction of hedges and tree lines) should be pursued to improve the landscape structure in the direction of greater biodiversity, as well as to protect soil against erosion by water and wind. A network structure with woody shelterbelts/corridors is thus to be promoted in the agricultural landscape (Ryszkowski 2002, Zajączkowski and Zajączkowski 2009).

\section{DISCUSSION}

The United Nations Food and Agriculture Organization (FAO) warns that food production will need to increase by at least $70 \%$ if the demands of a human population of 9 billion in 2050 are to be met. There are various advantages and disadvantages to increased food demand being met either through increased intensity of farming on current agricultural land with protected areas spared, or else through increased conversion of land to agriculture with a view to this being farmed using more biologically harmonious farming methods (i.e. land-sparing or land-sharing) - Tscharntke et al. (2012). Agroecological theory holds that landscapes composed of a high proportion of cropland are very susceptible to pest outbreaks, diseases, droughts, strong winds and other catastrophic events, due to their habitat homogeneity, and the decreased resistance and resilience of the system to climate changes (Tscharntke et al. 2005). Integration of land conservation (preservation of high diversity, non-used habitats) and arable land use appears to be an optimal strategy in complex landscapes of fragmented agrarian structure, whereas in simple landscapes there is merit to the separation of land conservation (habitat creation and reduced agricultural intensity) from land cultivation (Tscharntke et al. 2012).

It is widely recognised that agricultural production efficiency in Poland (subjected to global market trends and increasing competition) is much affected by the land-use pattern, with this seen to require merging and replacement procedures underpinned by sustainable development rules (Markuszewska 2013). However, bad soil quality and its vulnerability (in part combined with fragmented land-use structure) are implicated in considerable crop-yield losses. This is often a main reason for agricultural land to be abandoned by farmers, with the result being subsequent heavy encroachment by scrub. Given the present trend, the increase in the forested area of Poland to $33 \%$ by 2050 , as assumed by the National Programme, is very probable, though largely at the expense of agricultural land. This raises a question as to the long-term sustainable land-use strategies required to achieve both intensified and resource-efficient production of food, feed, wood and biomaterials and nature-protection aims under conditions of climate change.

It is of intrinsic importance that the field-forest boundary be organised simultaneously in the comprehensive management and planning of rural areas, with grassland ecosystems and woody elements in patchy landscapes also preserved. Diversified and integrated land use, protecting against climate variability and natural hazards, enhancing public 
amenity values and providing local products should be planned for by local stakeholders in disadvantaged areas, as a matter of priority.

In the agrarian arrangement process, special attention needs to be paid to areas with diverse land use mosaics, in which natural and cultural conditions should be brought within integrated local development strategies (Photos $1 \mathrm{a}, \mathrm{b}, \mathrm{c}$ ). This is important in particular in agricultural areas susceptible to erosion, as well as within protected areas with large number of woody patches (e.g. the Lublin Upland with its proneness to intense gully erosion - Photo $1 \mathrm{c}$. The areas characterised by fragmented land-use structure and variable (often low) soil quality offer new market opportunities for organic and traditional/local products, including via the use of woody strips to protect against environmental risks (wind, erosion and extreme weather fluctuations) or certain anthropogenic factors (intensive pesticide applications from neighbouring fields). When local stakeholders are directly involved in the effective management of local features of higher cultural and/or natural value and participate in the marketing of local innovative products, this may contribute significantly to rural development.

Overall, it can be noted that impaired food security does not stem primarily from a lack of food production, but rather from a lack of access to food of the desired quality, from social and procedural inequality, from the wasting of food and from poverty (Godfray et al. 2010, Garnett and Godfray 2012). Hence, sustainability needs to be viewed spatially and temporally, with a view to the indirect effects and consequences of different land-use policies that may impact on other regions and future generations being encompassed. This thesis is consistent with the goals of the Bioeconomy Strategy in Europe (EC 2012), as regards which the largest challenge is seen to be the production of sufficient biomass for the conversion of food, chemicals, fuel and bioplastics, while account is also taken of the need to maintain ecosystem functioning and preserve biodiversity. However, rural development as practised does not see the dual challenge developed more effectively by European agri-innovation policy (Levidow et al. 2012). It is therefore locally adapted, integrated land-use approaches that consider the multifunctionality of agricultural landscapes and are adjusted to needs that are necessary. Moreover, traditional agricultural landscapes with mosaic low-intensity farmlands are in particular susceptible to shocks and external inputs, from both social and ecological perspectives (Fischer et al. 2012). Therefore, as the optimal management of agricultural and forest space is considered, it is important that both local and regional aspects are taken account of in the long term.

The Common Agricultural Policy is at present focused on competitive and sustainable agriculture. The maintenance and development of multifunctional agriculture is at the centre of rural policy. In particular three measures under the RDP are of greater importance to the development of multifunctional agriculture in Poland: support for agricultural activity in less-favoured area (LFA), the agri-environmental programme and the afforestation of agricultural land. The important elements of the RDP 2014-2020 are the measures in support of innovative actions, farmers groups and the creation of operational groups. These measures could contribute considerably to 
building the knowledge base and facilitating learning among farmers through adaptive land-use management (including the mobilisation of wood resources) that respond better to needs of sustainable and inclusive bioeconomy.

\section{CONCLUSIONS}

To ensure appropriate spatial planning of rural areas in the direction of multifunctional development, the management of the landscape provided for in local spatial development plans should encompass integrated organisation of rural productive space, including by way of planning the field-forest boundary while retaining traditional landscape features. Woody elements offer a variety of options including buffer strips, well-planned woodlands and plantations, shelterbelts/windbreaks, hedges, anti-erosion belts, and alley-cropping agroforestry systems. Although the results of the studies point to an adverse effect of forest/woodland on grain-crop productivity within a distance equal to 1.5 times the height of trees on average, the effect is found to vary significantly in relation to soil quality and location. Equally, beyond the zone of impact in question it is possible to observe an increase in - or at least stability of - the yield, as compared with the average. These findings need further consideration in the light of the positive impact of shelterbelts/line belts with openwork-structure on crops. To properly manage strips along the forest edge, it is recommended that an edge/ecotone zone covered by multi-species vegetation with diversified vertical and horizontal structure be established. Modern agroforestry systems could be an important part of the transition zone between the forest/field-forest boundary and agricultural land, in accordance with local spatial development plans and ecological infrastructure. Supplementary afforestation (including the introduction of shelterbelts and strips in different adapted configurations) should be implemented to improve the landscape structure in the direction of greater biodiversity, as well as to protect crops and soil against water and wind erosion and also human factors (pesticide application, nutrient leaching).

However, this is not a trivial task due to trade-offs between different land uses, and for a number of reasons that inter alia include the abandonment of agricultural land mostly characterized by poor soil quality, the need to preserve a local traditional landscape where the natural and cultural features are of high value, and - last but not least - the plot-distribution pattern where Polish farms are concerned. The last factor seems extremely important, since the analysis performed showed large variations of farm areas as well as of land plots between different regions and municipalities, this obstructing equitable access to the EU support system and hindering competitiveness among farmers, with the result that the lack of social cohesion characteristic of rural areas is made worse. Moreover, despite the problems in implementing the afforestation programme, new legislative and conceptual opportunities are arising, with the result that innovative approaches to integrated land use are now needed. These would combine the creation of public goods, renewable biological resources and local food products, 
and would be based on participatory learning processes involving local stakeholders and decision makers. Such a proposal therefore requires a careful assessment of risks and interests, but this is an activity that could well be worth pursuing.

\section{REFERENCES}

Bielska A., Kupidura A., 2009, Influence of soil conditions on landscape shaping in rural areas, Chapter 6, [in:] Contemporary problems of management and environmental protection, Vol. 3, Natural and cultural transformation of landscape, 67-82.

Brzeziecki B., 2001, Zasady zakładania i pielegnowania leśnych stref ekotonowych, (The principles of establishment and management of forest ecotones zones), Katedra Hodowli Lasu, SGGW, Warszawa.

EC (European Commission), 2012, Communication from the Commission to the European Parliament, the Council, the European Economic and Social Committee and the Committee of the regions-Innovating for sustainable growth: A bioeconomy for Europe, Brussels, Belgium, European Commission.

Fischer J., Hartel T., Kuemmerle T., 2012, Conservation policy in traditional farming landscapes, Conservation Letters, 5, 3, 167-175.

Garnett T., Godfray H. C. J., 2012, Sustainable intensification in agriculture: navigating a course through competing food system priorities, Oxford, UK: Food Climate Research Network and the Oxford Martin Programme on the Future of Food, University of Oxford.

Godfray H. C. J., Beddington J. R., Crute I. R., Haddad L., Lawrence D., Muir J. F., Pretty J., Robinson S., Thomas S. M., Toulmin C., 2010, Food security: the challenge of feeding 9 billion people, Science, 327, 812-818.

Jakubczak Z., Wołk A., 1977, Wpływ zadrzewień na warunki agroekologiczne oraz plonowanie roślin uprawnych, (The impact of afforestations on agroecological conditions and agricultural crops productivity) [in:] Znaczenie zadrzewień $w$ ksztaltowaniu przyrodniczego środowiska czlowieka (The importance of afforestations for the shaping natural conditions of human environment), Materiały z konferencji naukowej, (Proceedings of the Conference), Sękocin, part I.

Jędrejek A., Szymański L., Woch F., 2014, Evaluation of the plot size (farm land) of family agricultural holdings and the needs for land consolidation in Poland, Infrastructure and Ecology or Rural Areas, Nr. IV/1/2014, 1111-1125.

Kaliszewski A., 2012, Problemy realizacji „Krajowego programu zwiększania lesistości” po wstapieniu Polski do Unii Europejskiej, (Problems implementing the „National Program for Expanding of Forest Cover" following Poland's accession to the European Union), Leśne Prace Badawcze (Forest Research Papers), 73, 3, 189-200.

Krajowy program zwiększania lesistości, (National Programme for the Augmentation of Forest Cover), 1995, http://www.mos.gov.pl/artykul/326_lesnictwo/296_krajowy_program_zwiek szania_lesistosci.html

Kulig L., Nowak M., Smólski S., Zoil F., 1959, Zasady ustalania granicy między użytkami rolnymi i leśnymi w okolicach górskich, (The principles for the designing boundaries between agricultural and forest lands), Zeszyty Problemowe Postępów Nauk Rolnych, 19, 3-36. 
Kupidura A., 2010, Management of the agricultural landscape in land consolidation projects in Poland, The Problems of Landscape Ecology, 28, 163-169, http://paek.ukw.edu.pl/pek/index. php/PEK/article/view/981/851

Lekan Sz., Tałałaj Z., Węgorek T., 1993, Ocena wpływu zadrzewień klimatyczno- melioracyjnych na Żuławach Gdańskich na plonowanie roślin rolniczych (The assessment of impact of agroclimatic-drainage afforestation system on agricultural crops productivity on the Żuławy Gdańskie region), Typescript, IUNG, Puławy, 23 pp.

Leśnictwo 2014, Informacje i Opracowania Statystyczne, 2014, (Forestry 2014, Statistical Information and Elaborations), Główny Urząd Statystyczny, (Central Statistical Office), Warsaw, http://stat.gov.pl

Levidow L., Birch K., Papaioannou T., 2012, EU agri-innovation policy: two contending visions of the bio-economy, Critical Policy Studies, 6, 1, 40-65.

Markuszewska I., 2013, Land Consolidation as an Instrument of Shaping the Agrarian Structure in Poland: A Case Study of the Wielkopolskie and Dolnoślaskie Voivodeships, Quaestiones Geographicae, 32, 3, 53-67, http://www.degruyter.com/view/j/quageo.2013.32.issue-3/ quageo-2013-0027/quageo-2013-0027.xml

Molga M., 1983, Agrometeorologia, (Agrometeorology), PWRiL, Warszawa, 491 pp.

Podolski B., Woch F., 1999, Wplyw bezpośredniego oddziaływania lasów i zadrzewień śródpolnych na plonowanie zbóż ozimych (The impact of forests and mid-field woodlands on winter cereals productivity), Pamiętnik Puławski, 119, 101-111.

Ryszkowski L. (ed.), 2002, Agroecosystems management, CRC Press, 384 pp.

Ryszkowski L., Bałazy S., Jankowiak J., 2000, Program zwiększania zadrzewień śródpolnych, (Program for increasing midfield afforestations), Postępy Nauk Rolniczych, 47, 5, 83-107.

Ryszkowski L., Kędziora A., 1987, Impact of agricultural landscape structure on energy flow and water cycling, Landscape Ecology, 1, 2, 85-94.

Ryszkowski L., Kędziora A., 2007, Modification of water flows and nitrogen fluxes by shelterbelts, Ecol. Eng., 29, 388-400.

Stuczyński T., Kozyra J., Łopatka A., Siebielec G., Jadczyszyn J., Koza P., Doroszewski A., Wawer R., Nowocień E., 2007, Przyrodnicze uwarunkowania produkcji rolniczej $w$ Polsce, (Natural conditions of agricultural production in Poland), Studia i Raporty IUNG-PIB, 7, 77-115.

Tałałaj Z., 1997, Wplyw zadrzewień na planowanie roślin rolniczych (The impact of afforestations on agricultural crops productivity), [in:] Znaczenie zadrzewień w krajobrazie rolniczym oraz aktualne problem ich rozwoju w przyrodniczo-gospodarczych warunkach Polski, (The importance of farmland afforestations in agricultural landscape and the present problems of their introduction under natural and economic conditions of Poland), Proceedings of the Conference, Provincial Authority in Płock, 72-90 pp.

Tscharntke T., Clough Y., Wanger T. C., Jackson L., Motzke I., Perfecto I., Vandermeer J. and Whitbread A., 2012, Global food security, biodiversity conservation and the future of agricultural intensification, Biological Conservation, 151, 1, 53-59.

Tscharntke T., Klein A. M., Kruess A., Steffan-Dewenter I. and Thies C., 2005, Landscape perspectives on agricultural intensification and biodiversity-ecosystem service management, Ecology Letters, 8, 857-874. 
Ustawa o lasach z dnia 8 września 1991, (Act on Forests of 28 September, 1991), Dziennik Ustaw, numer 101, pozycja 44, (Journal of Laws, number 101, item 44), http://isap.sejm. gov.pl/DetailsServlet?id=WDU19911010444

Ustawa o scalaniu $i$ wymianie gruntów z dnia 29 lipca 2011, (Act on Land Consolidation and Exchange of 29 July 2011), Dziennik Ustaw, numer 185, pozycja 1097, (Journal of Laws, number 185, item 1097).

Ustawa o ksztaltowaniu ustroju rolnego z dnia 11 kwietnia 2003, (Act on Shaping of the Agrarian System of 11 April 2003), Dziennik Ustaw, numer 64, pozycja 592 (Journal of Laws, number 64, item 692).

Węgorek T., 1997, Znaczenie zadrzewień w przeciwdziałaniu wodnej i wietrznej erozji gleby, (The importance of farmland afforestations in wind and water soil erosion control), [in:] Znaczenie zadrzewień w krajobrazie rolniczym oraz aktualne problemy ich rozwoju w przyrodniczogospodarczych warunkach Polski, (The importance of farmland afforestations in agricultural landscape and the present problems of their introduction under natural and economic conditions of Poland), Matateriały Konferencyjne, Płock, (Proceedings of the Conference, Provincial Authority in Płock), 28-39.

Woch F., 1996, Wytyczne do projektowania granicy rolno-leśnej, (Guidelines on designing of rural-forest boundary), Typescript, IUNG, Puławy, 35 pp.

Woch F., 2001, Optymalne parametry rozłogu gruntów gospodarstw rodzinnych dla wyżnnych terenów Polski, (Optimum parameters of the plot size and distribution for private farm holdings in upland areas of Poland), Pamiętnik Puławski, 127, 105 pp.

Woch F. (ed.), 2006, Kompleksowe scalenie gruntów rolnych i leśnych oraz jego wptyw na środowisko, (Complex consolidation of agricultural and forest lands and its impact on the environment), Materiały szkoleniowe, (Training materials), Number 93, IUNG Puławy, 175 pp.

Woch F., Kochański S., Podolski B., 1993, Ustalanie granicy rolno-leśnej $w$ procesie urzadzenioworolnym, (The designing of rural-forest boundary in the arranging-agrarian process), Prace Nauk. Polit. Warszawskiej, Geodezja, 32, 99-105.

Woch F., Tałałaj Z., 2007, The problems of lands afforestation and of rural-forest boundary shaping, [in:] Woch F. (ed.), Wademekum klasyfikacji gleb, (Vademecum of the soil classifier), IUNG Puławy, 327-370.

Wytyczne w sprawie ustalenia granicy rolno-leśnej, 2003, (Guidelines on designing of ruralforest boundary), Ministerstwo Rolnictwa i Rozwoju Wsi we współdziałaniu z Ministerstwem Środowiska, (Ministry of Agriculture), Warszawa.

Zajączkowski K., 2005, Regionalizacja potrzeb zadrzewieniowych w Polsce, (Regionalization of agricultural landscape needs for shelterbelts and woodlots in Poland), Prace IBL, Rozprawy i Monografie, (Papers of the Forest Research Institute, Dissertations and Monographs), Warszawa, 4, 127 pp.

Zajączkowski J. and Zajączkowski K., 2009, Farmland afforestations: new goals and guidelines for Poland, Folia Forestalia Polonica, Series A, 51, 1, 5-11.

http://mapy.geoportal.gov.pl/imap/?gpmap=gp0 